\title{
Tendencies of the Christian educational institutions architecture development as based on the example of the Catholic University of America पी
}

\begin{abstract}
The article analyzes the peculiarities of architectural and space-planning organization of campuses in Christian higher educational instutions as based on the example of the Catholic University of America in Washington, depicts the history of the university establishment process, outlines the development of its architecture within the perspectives of time and space, highlights the major tendecies that define the formation of architecture of buildings, facilities and spaces in contemporary higher educational institutions, which carry out their educational and scientific activities under the guidance of the Christian Catholic Church ideology.
\end{abstract}

Keywords: Catholic Church, education, science, architecture, temple, university, campus.

\section{Introduction}

The contemporary higher education is dynamic and flexible in its nature and can be characterized by an active implementation of brand-new educational methods and achievements of advanced informational technologies. Nonetheless, in most cases, education lacks a clear-cut ideological definition. While referring to ideology, we mean the spiritual ideology. The young generation of students, who live in the age of world globalization, face a lot of challenges and life temptations. Finding the right direction to go and figuring out the place to stay are the most important steps in the stormy sea of modern ideologies and worldviews. Having no well-established spiritual principles, students can easily fall under the influence of the contemporary ideological tendencies and pseudosciences. The absence of a steady spiritual core leads to the gradual loosening of consciousness and, as a result, degradation of a personality. The problem is more than topical in the situation when the informational space is oversaturated. The majority of yound people look for the education which would go beyond the task of making them highly qualified specialists, but also take into account the everlasting Christian values and the Christian worldview. At the dawn of education, these were theological schools, seminaries, academies and universities that played the role of a cradle of education and science [2]. The most prominent examples of Christian universities located around the globe provide the justification for the assumption that theological-humanitarian and theological and natural sciences higher education is not a relic of the past, but an effective way to the genuine high-quality education and the advanced science. The larger is the number of such educational instutions, the sooner will come the moment of finding the common consent and resolving the global worldview and ideological deadlocks.

The establishment of new theological-humanitarian and theological and natural sciences educational instutions is impossible without having a proper organization of the educational process and, what is more, without organization of the corresponding architectural environment, which includes the complex of buildings, facilities, spaces and territories. The architectural and space-planning organization of campuses in Christian universities is considerably different from the space-planning structure of purely secular higher educational establishments [3]. Recently, there have been conducted a lot of researches on the issue of 
secular university complexes and their architecture development, but the specificity of Christian universities architecture requires further profound investigation. The detailed study of architecture of theological-humanitarian and theological and natural sciences educational institutions will make it possible to work out the design methodology and introduce the necessary additions to the regulation documents, guiding the process of designing and constructing institutions of this type. The possibility is particularly important for the reviva type. The possility is partician education in the revival of theological during the recent years has found Ukrainian society, which ding process of the dive searitual identity. the current research is the building complex of the Catholic the current research is the building compity of America in Washington, USA

\section{The aim of the publication}

The aim of the publication is to analyze the characteristic features of the building complex architecture of the Catholic University of America (Washington, USA), which is a typical theological-secular higher educational institution, established by the Catholic Church in the USA, and to define the major tendencies of buildings, facilities, spaces and territories architecture development in theological-humanitarian and theological and natural sciences higher educational institutions.

3. The analysis of recent researches and publication The architecture development of theological and theological-secular educational institutions has been researched by a wide range of Ukrainian scholars, architects, art historians, and historians. Among them, it is necessary to emphasize the scholarly contribution of V. I. Proskuryakov, a PhD, R. Z. Stotsko, a PhD candidate $[1,2,3,4,5]$, and O. I. Zhovkva, a PhD candidate, who have researched the architecture development of theological educational institutions of the Ukrainian Greek Catholic Church and the Orthodox Churches. The and architects focus on the following The pects: L. Shuldan studies the topic of education insting aspechitec [14] O. Lesyk, Yu. V. Idak, B. M. Khikhlich L

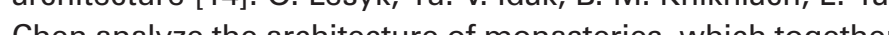
with other the wh of of theological education. Apart from that, R. Halyshych in his research describes the Ulrainian church architecture and the monumental and decorative art of the foreign communities, Yaroslav Taras studies the sacred wooden architecture in Ukraine of the X-XXIC., O. O. Lesyk-Bodnarchuk researches the topic of the professional architectural activity within the temple construction process in the Volyn region, H. Yurchushyn and Yu.l. Kryvoruchko investigate the theological foundations of sacred architecture [13], Ya. Kravchenko delves into the role of a church ensemble in the bullding space organization of the Hutsul settlements back in the XVII-XX c., V. I. Turchyn studies the bearers of traditions in the sacred architecture of Ukraine [9], B. S. Cherkes researches the traditions and selfidentity in the contemporary Ukrainian church architecture S. Linda works on problems of the contemporary sacred architecture development in Ukraine, Yu.Ya. Dubyk explores the sacred architecture restoration, V. Yarema Western Ukraine, $\mathrm{H}$. Shevchuk explores the building constructions of sacred objects, A. S. Ivchenko describes the most famous temples in Ukraine.

Having analyzed the current stage of research in the area of the Ukrainian theological schoo building architecture, we would like to emphasize that the topic has bem like to emphasize that the topic has been investigated in details only by a limited number of archprofoundness and calls for the further study.

\section{The main part}

The necessity of having a higher theological institution in the United States of America has been repeatedly discussed at different level of the US officials and the Catholic Church governance. At the Second Plenary Council of Catholic Bishops in Baltimore in 1886, it was decided to establish the Catholic University of America (CUA). On April, 10, 1887, Pope Leo XIII issued an official permission to establish the university, the primary aim of which was to strengthen the positions of the Catholic Church in the USA. The university, located on the territory of 27 hectares, was opened in 1887. The territory bordered with the old military barracks. The educational process in the university started in November, 1889. At first students used to study the Holy Scripture, the ology, philosophy, English literature and canon law. Already in 1900, the Catholic University of America adopted the German model of doctoral training and scientific research performance, and entered the Associaton of Am can Universities. Notably, the university was open for students of the Afro-American which was a rare case for those times [G. During the World War Il, the Catic U Dity of A Werica sity of America in Washington becane the center of spiritual life in the United States. The facilites and buildings, located on the surrounding streets, were rented by different Christian organizations. After the War, the university expanded its educational area in order to accept the large number of veterans, who expressed the desire to acquire theologicalhumanitarian education. Today, the CUA hosts almost six thousand students from around the world and almost seven hundred lecturers. The Catholic University of America belongs to the limited number of higher educational institutions, which were visited by three popes. The Catholic University of America unites the following educational and scientific depart- ments: School of Theology and Religious Studies, School of Service, School of Architecture and Planning, School of Arts and Sciences, School of Business and Economics, School of Engineering, School of Library and Information Science, School of Music, Center for Advancement of Catholic Education, American Catholic History Research Center, Center fo Catalan Studies, Center for Irish Studies, Center for Medieval and Byzantine Studies, Center for Pastoral Studies, Center for and Byzantine Studies, Center the Study of Culture and Values, Center for the Study of Early ar Bioly, Center the Study of Energy and EnvironecuTeronmenCechnology Center, Institu for Christind Oriental Research, Institute for Com Ca holic Studies, Insties, of Sacred Moricy hesearch and Catholic Studies, Institute of Sacred Music, Institute for Social Justice, Institute of Musical Arts, Institute for Astrophysics and Computational Sciences, Institute for Biomolecular Studies. The Catholic University is the only university in the USA that grants canonical diplomas in three theological disciplines at once: canonic law, theology and philosophy [6]. The CUA academic campus is located in a picturesque res dential area of Brookland at Michigan Ave, at $5 \mathrm{~km}$ distance from the Capitol building (ill. 1). Today, the total area of the campus is equal to 78 hectares. The main architectural dominant of the Catholic University of America complex is the Basilica of the National Shrine of the Immaculate Conception designed in the Roman style (ill. 2, 3, 4). In front of the Basilica through the green lawn, there is a building of the old library, designed in the traditional classical style (ill. 5). The lawn is the center of the university campus. It is surrounded by the old academic, residential and administrative buildings. Together with the Basilica and the library, these old buildings create the unique ensemble of the traditional North American architecture of the XIX - early XX c. (ill. 6). In the CUA academic campus, there is also the Palace of Cardinals (ill 6). The building of gray stone reminds the style of the Medi. The buld of building triggrs im the

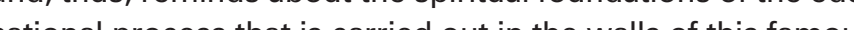
The

The educational doctrine of the Catholic University of America combines the traditional Christian values, the century-long philosophy and the theological teachings with the most advanced knowledge from the area of humanitarian and natural sciences of the modern times. The symbiosis of the conservative traditionalism and the progressive modernism is reflected in the university campus architecture [4]. Moder academic buildings are erected right next to the old ones. The landmark of the complex is the The Edward J. Pryzbyla University Center (ill. 7), which houses the students' administrative offices, the library, the book store, the food production facility with a large banquet hall for 800 people. The high-tec style of the building architecture, which stands in a strong contrast with the stylistics of the Basilica and the old aca- demic buildings, underlines the modern and the Catholic University of America. The façades and interiors of the Edward J. Pryzbyla University Center are made of lightweight constructions with the extensive use of metal, glass and composite materials. Such space-planning and stylistic solutions appeal to young students, who eagerly spend here a lot of time while tudying and having rest. The spacious law in front of the center is the commacious lawn the conferences, exhibieon, lectures and discussons, as well as the concerts and the theatre group performancthe Center, there is the academic building of the Cer a ming aristecture with is is designed in a minimalist style with simple geometric space-planning organization and semi-cylindrical roof. This functional building, which lacks any exaggerated décor, is comfortable or the creative workshops

The new residential buildings of the university are simple in terms of their space-planning organization and architectural outlook, bu the functional solutions of the interior are well thought over. This aspect is crucial for ensuring the most comfortable conditions of students' life, studying and recreation activities The architectural and space-planning organization, as well as the stylistic and decoration finish of the Catholic University of America campus buildings, follow precisely the tendencies of architecture development observed in the theological-humanitarian and the theological and natural sciences higher ed the Catholic University in Lviv) [2]:

Academic campuses of the theological-humanitarian and the theological and natura ciences higher educational institutions (universities) are located in metropolises near to other educational institutions, libraries, scientific and cultural centers.

Architectural and space-planning organization of building complexes of the theologicahumanitarian and the theological and natur sciences higher educational institutions (universities) is formed as based on the building of the theological educational institutions (theological schools, theological seminaries, theological academies), or on the building constructions of a separate temple and related premises and buildings.

Buildings of academic campuses are located around the open space, which might be 


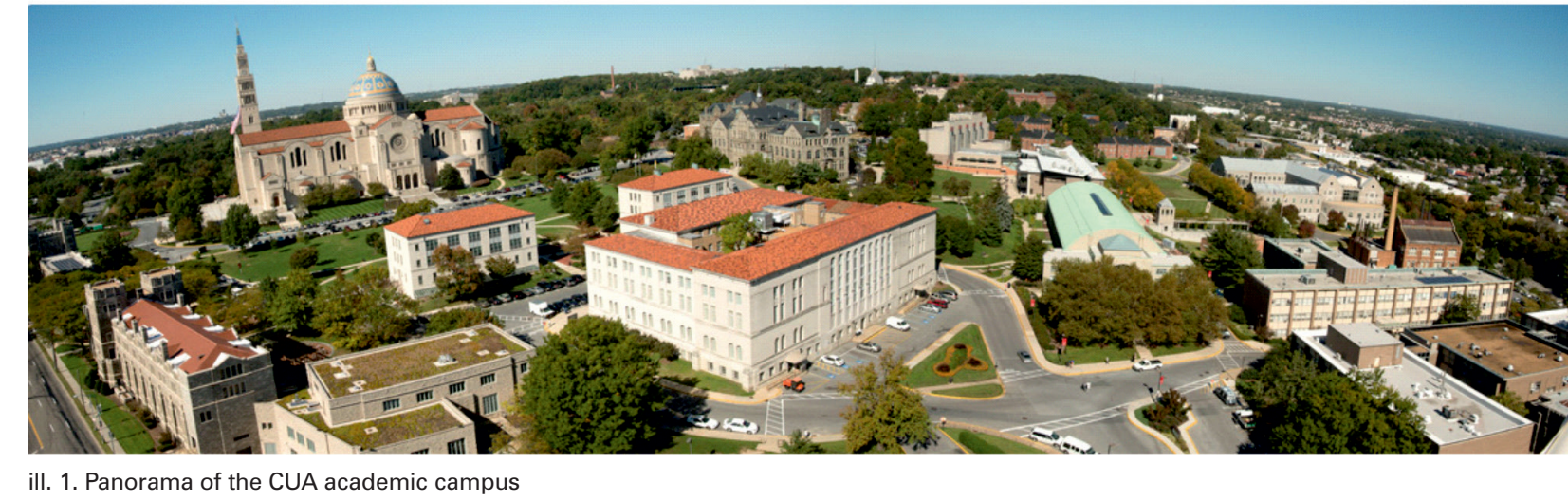

a square or a recreational green territory.

Temple is the dominant building of the university campus and can be located in the following way: (a) on the central axe of the complex right at the main street: (b) on the central axe at the back of the complex; (c) in the geometric center ax the complex; (d) aside from the central axe right at axe omplex.

Apart from the main temple, there are other chapels settled in the academic and residential buildings and the adjacent spaces.

University library building is visually and transitionally connected with the temple and creates one of the main axes of he complex.

Academic buildings are located around the temple and their main façades are turned to it.

Administrative building is located at the main street near to the central entrance to the complex territory.

Laboratory buildings are located at the periphery and have good transport connections with the streets of metropolis. Residential buildings are located in green areas of the academic campus and ensure logistics with the academic buildings, library, food production unit and household unit. Usually, architects, while designing the complex, ensure visual

connection of the residential buildings with the temple building.

All buildings of the academic campus should have well-developed entrances, turn-around areas and parking lots.

From the viewpoint of the architectural and space-planning organization of its campus, the Catholic University of America belongs to the theological-secular educational institutions of the open type [1]. The university campus terity does not have any fence, the cuildings are locat frely and do not crete a closed structure, the temple is avalable for the city parishioners. This type of arable for and space is space-planning organization of campuses is com reflects the theological and educational ideology of the Catholic Church, which is focused on the idea of openness, the ecumenical dialogue and the priority of human values [7]. For many decades, the successful educational an scientific activities of the Catholic University of America have been proving the continuity of the Christian worldview and the scientific- ill. 2. Basilica main façade
ill. 3. Basilica of the National Shrine of the Immaculate Conception flank façade
ill. 4. Basilica interior

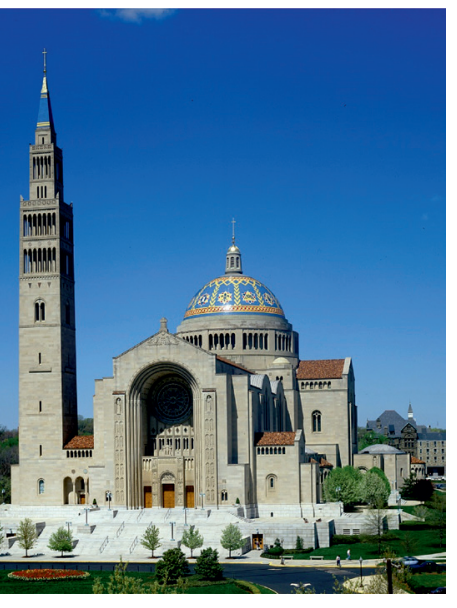

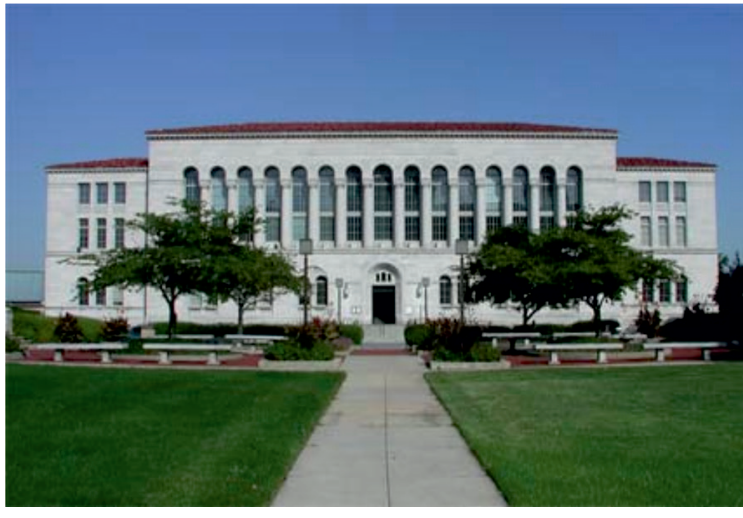

ill. 5. University library
ill. 6. Palace of Cardinals

pus. The combination of sacred and traditional architecture of the XIX- early XX c. with the modern architecture of new academic buildings symbolizes the unbreakable connection of generations, scientific and educational knowledge on the basis of the Christian worldview.

The example of campus architecture of the Catholic University of America makes it possible to outline the general tendencies of architecture development of the theological-secular Catholic educational institutions: academic campuses of the theological-humanitarian and the theological and natural sciences higher educational institutions are located in metropolises near to other educational institutions, libraries, scientific and cultural centers. Architectural and space-planning organization of building complexes of the theological-humanitarian and the theological and natural sciences higher educational institutions is formed as based on the buildings of the theoinstitutions is formal institutions, or on the building contruclogical educatorate ins. Buildings of academic campuses are located around the open space, which might be a square or a recreaund the open space, which mich be a square green territy. The which is migh be a square or a recreationa chide residential bullings and the adjacent spaces. University library building is visually and transitionally connected with the temple. Academic buildings are located around the temple and their main façades are turned to it. Administrative building is located at the main street near to the central entrance to the complex teritory. Laboratory buildings are located at the periphery. Residential buildings are located in green areas

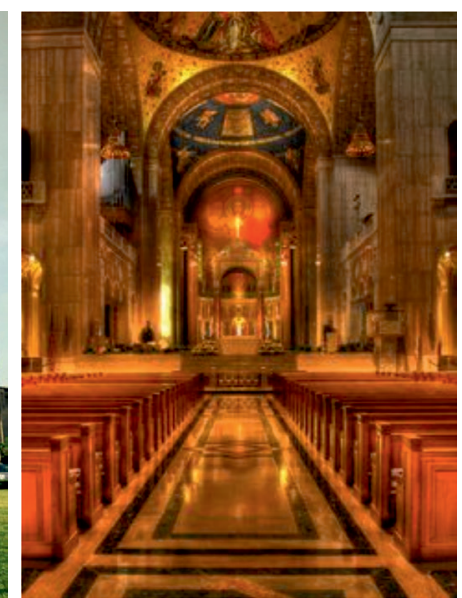

IIl. 7. The Edward J. Pryzbyla University Center

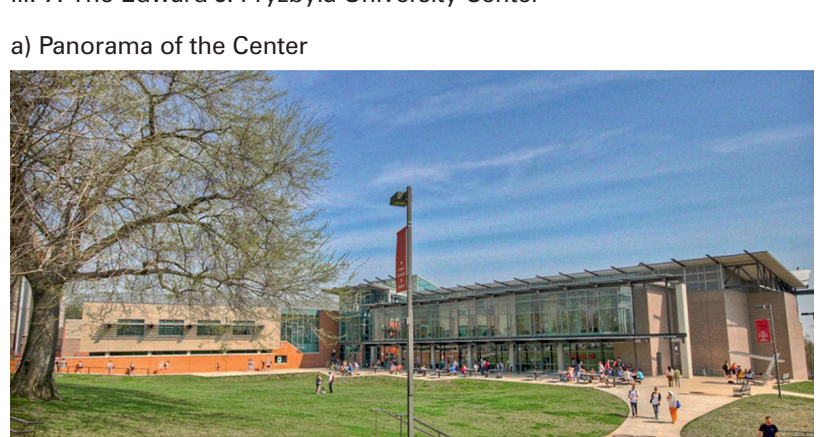

and-educational advance of the mankind, and the inseparability of the traditional knowledg and the innovative ideas. The complex archtecture by itself emphasizes the connection of spiritual and material, traditional and modern eternal and unexplored. The connection of old building stylistics with the modern building design does not trigger the feeling of dissonance, but underlines the continuity of knowledge and experience, the constant flow of time and the human desire of reaching new horizons in education and science.

\section{Conclusions}

Theological education used to be and currently remains the foundation of secular education, which is based on the principles of human values and the Christian worldview. Together with the purely theological and the Turely puritions, purition and ties, which function as the symbiosis of relithes, which function as the symbiosis of relUniver and secular education. The Catholic Universiy of America is the bright example of this type of universities. The theologica and educational ideology of the university is reflected in the architectural and spaceplanning organization of its academic cam-

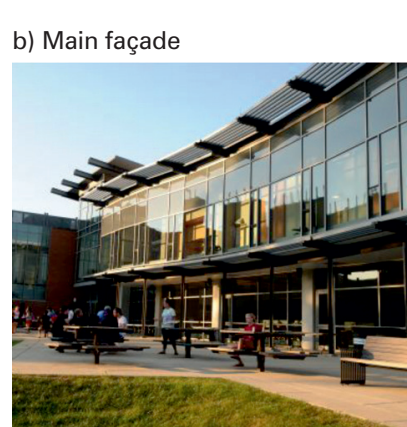

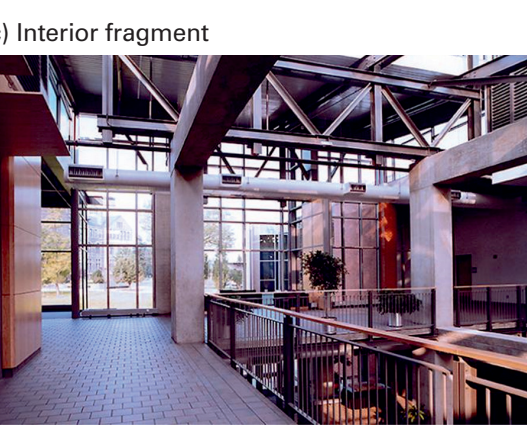


of the academic campus and ensure logistics with academic buildings, library, food production unit and household unit. All buildings of the academic campus should have well-developed entrances, turn-around areas and parking lots. Architectural and space-planning organization of the Catholic University of America academic campus is common for the Catholic universities and reflects the theological and educational ideology of the Catholic Church, which is focused on the idea of openness, the ecumenical dialogue and the priority of human values

\section{BIBLIOGRAPHY:}

[1] V. Proskuryakov, R. Stotsko. Architectural-planning and social principles of formation of higher theological education centers of Ukrainian Greek-Catholic Church in Ukraine // The Herald of NU "Lviv Polytechnic". - Nr. 585. - Lviv, 2007. - P. 133-140.

[2] V. Proskuryakov, R. Stotsko. Modern architectural tendencies of projecting and construction of theological educational institutions // Collection of scholarly works. - Issue No 5. - Kyiv Regional Research and Development Institute of Civil Engineering, 2004. - P. 109-114.

[3] V. Proskuryakov, R. Stotsko. Genesis of theological education in Ukraine and formation of new principles of theological educational institutions // Collection of scholarly works. - Issue No 5. - Odessa, Odessa State Academy of Civil Engineering and Architecture, 2004. - P. 206-210.

[4] V. Proskuryakov, R. Stotsko. Architectural and space-planning organization of the building complex of Lviv Theological Seminary in 1783-1945 // Collection of scholarly works. - Issue No 1-2. - Kharkiv, Kharkiv State Academy of Design and Fine Arts, 2004. - P. 157-160.

[5] V. Proskuryakov, R. Stotsko. Integration of educational architectural projects into the process of creating a new theological center in Lviv // Materials of the research and practice conference, Prydniproska State Academy of Civil Engineering and Architectre. - Dnipropetrovsk, 2005. - P. 75-79.

[6] https://en.wikipedia.org/wiki/Catholic University of America

[7] Speech of father Bokhdan Prach, Phd, at the opening of UKU academic building at 29 Stryiska Str. // UCU collection of reports, speeches and discussions - Lviv, 2013. - P.27-30.

[8] I. Holovach, M. Marynovych, A. Yasinovskyi. Identity and mission of the Ukrainian Catholic University // UCU collection of reports. - Lviv, 2003. - P. 33-39.

[9] V. Turchyn. Bearers of tradition in Ukrainian sacred architecture // The Herald of NU "Lviv Polytechnic". - Nr. 410. - Lviv, 2000. - P. 231-235.

[10] M. Lahodych. Theological education in Ukraine: current state and perspectives// Topical questions of religious and theological studies: Collective mono- graph / Ed. by V.O.Balukh. - Chernivtsi: Chernivtsi national university, 2010. - P. 229-246.

[11] Education Buildings: Eloquent Resistance // Canadian Architect. - May 1997. - Vol. 42, 5. - P. 15-24.

[12] Andrew Gulliford. America's Country Schools. Washington, D.C., 1990. - 296 p.

[13] Yu. Kryvoruchko. Theological grounds of sacred architecture // The Herald of NU "Lviv Polytechnic". - Nr. 410. Lviv, 2000. - P. 3-8.

[14] V. Proskuryakov, L.Shuldan. Experience of designing and constructing modern schools and complexes in Ukraine and abroad with implementation of energy saving ideas // Regional problems of architecture and urban planning: Collection of scholarly works. - Odessa, 2005. - Nr. 7-8. - P. 110-123.

\section{SOURCES AND AUTHORS OF IMAGES USED IN THE} ARTICLE

ill. 1. Panorama of the Catholic University of America academic campus / Catholic University of America [Electronic Resource]. - Mode of access: URL: https://www.cua.edu/ - Title from the screen

ill. 2. Basilica main façade / Catholic University of America [Electronic Resource]. - Mode of access: URL: https://www. cua.edu/ - Title from the screen.

ill. 3. Basilica of the National Shrine of the Immaculate Conception flank façade / Catholic University of America [Electronic Resource]. - Mode of access: URL: https://www.cua. edu/ - Title from the screen.

ill. 4. Basilica interior fragment / Catholic University of America [Electronic Resource]. - Mode of access: URL: https:// www.cua.edu/ - Title from the screen.

ill. 5. University library / Catholic University of America [Electronic Resource]. - Mode of access: URL: https://www.cua. edu/ - Title from the screen.

ill. 6. Palace of Cardinals / Catholic University of America [Electronic Resource]. - Mode of access: URL: https://www. cua.edu/ - Title from the screen.

ill. 7(a). Panorama of the Center / Catholic University of America [Electronic Resource]. - Mode of access: URL: https:// www.cua.edu/ - Title from the screen.

ill. 7(b). Main façade / Catholic University of America [Electronic Resource]. - Mode of access: URL: https://www.cua. edu/ - Title from the screen.

ill. 7(c). Interior fragment / Catholic University of America [Electronic Resource]. - Mode of access: URL: https://www. cua.edu/ - Title from the screen. 